\title{
EVALUACIÓN IN VITRO DE LAS CAPACIDADES PROBIÓ- TICAS MICROBIANAS ORIENTADAS AL DISEÑO DE INÓCULOS PROBIÓTICOS MULTIESPECIE PARA SER UTILIZADOS EN LA CRIANZA DE TERNEROS
}

\author{
FRIZZO, L. S. ${ }^{1 ;}$ SOTO, L. P. ; BERTOZZI, E. ; \\ Sequeira, G. ${ }^{1}$; Marti, L. E. ${ }^{1}$; \& Rosmini, M. R. ${ }^{1}$
}

\begin{abstract}
RESUMEN
El uso de microorganismos autóctonos con capacidad probiótica es una herramienta alternativa para el tratamiento y prevención de algunas patologías animales. La eficacia de las cepas seleccionadas debe ser comprobada antes de que estas sean suministradas a los animales. Para ello, se utilizan una serie de criterios que permiten determinar in vitro algunas propiedades probióticas. Es conveniente que el inóculo a utilizar en los animales esté formado por una mezcla de varias cepas, de forma que entre ellas puedan complementar sus efectos expresando sus propiedades probióticas en forma sinérgica. El objetivo de este estudio fue caracterizar un grupo de bacterias ácido lácticas aisladas a partir de terneros lactantes sanos, mediante pruebas in vitro para considerar su posterior aplicación durante la alimentación en la etapa de crianza de los terneros. Se observó la producción de una sustancia antimicrobiana por parte de P. acidilactici DSPV 006T la cual podría generar efectos benéficos durante el tránsito intestinal que contribuyan al balance de la microbiota. La capacidad de autoagregación de L. salivarius DSPV 315T junto la gran performance de crecimiento y sobrevivencia a los jugos gástricos de L. casei DSPV 318 T hacen que estas 3 cepas posean características que permitan predecir ventajas competitivas, frente a las otras estudiadas, al momento en que tengan que actuar en los animales. Estas propiedades demuestran que las cepas son buenos exponentes para ser incorporados a la dieta de los terneros como un inóculo probiótico multiespecie.

Palabras clave: bacterias ácido lácticas, terneros, propiedades probióticas, probióticos multiespecies
\end{abstract}

1.- Departamento de Salud Pública Veterinaria (DSPV), Facultad de Ciencias Veterinarias, Universidad Nacional del Litoral. Kreder 2805 (S3080HOF) Esperanza, Santa Fe.

E-mail: lfrizzo@fcv.unl.edu.ar

Manuscrito recibido el 24 de octubre de 2006 y aceptado para su publicación el 11 de diciembre de 2006. 


\section{SUMMARY}

\section{In vitro evaluation of the microbial probiotic capacities focused to design of multispecies probiotic inocula to be used in breeding of calves.}

The use of indigenous microorganisms with probiotic capacity is an alternative tool for the treatment and prevention of some animal pathologies. The efficacy of the chosen strains must be verified before these are given to the animals. For it, a series of criteria are used to determine some in vitro probiotic properties. It is suitable that the inoculum to be used in the animals is formed by a mix of several strains, so that they could complement their effects and express sinergically their the probiotic properties. The aim of this study was to characterize a group of lactic acid bacteria isolated from nursing healthy calves, by means of in vitro assay to be considered for administration during the feeding in the breed stage of calves. The antimicrobial substance produced by P. acidilactici DSPV 006T can generate beneficial effects during the intestinal transit and contribute to the balance of the microbiota. The autoaggregation capacity of $L$. salivarius DSPV $315 \mathrm{~T}$ and the higher performance of growth and the survival to the gastric juices of $L$. casei DSPV $318 \mathrm{~T}$ suggests that these three strains possess characteristics that allow to predict competitive advantages compared to other organisms in actual conditions of use in animals. These properties suggest that the strains are good exponents to be incorporated into the diet of the calves as a multispecies probiotic inoculum.

Key words: lactic acid bacteria, calves, probiotic properties, multispecies probiotics. 